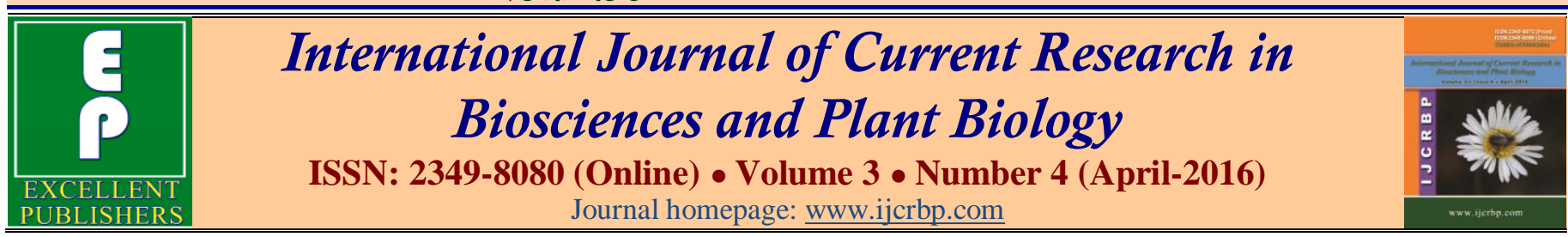

\title{
Allelopathy: A Green Approach for Weed Management and Crop Production
}

\author{
Raghvendra Saxena*, Rajesh Singh Tomar and Manish Kumar \\ Amity Institute of Biotechnology, Amity University Madhya Pradesh, Gwalior, Madhya Pradesh, India \\ *Corresponding author.
}

\begin{abstract}
A bstract
Agricultural crop production is always under threat of different of environmental challenges which leads to decline crop productivity to a significant extent, among various factors weeds are the most notorious agent, that not only cause drastic decline the crop production in major crops but also effect negatively on soil health too. Since, there is a continuous pressure of growing population to cope with inflating need of food demand. There is a constant need to identify the area to address the weed mediated decline in crop production. Allelopathy could be a most promising tool for sustainable agricultural production, by suppressing the weed growth and prevention of weed resistance to toxic chemical herbicides. Variety of different classes of allelochemicals are identified and assayed for their allelopathic potential, either alone or as combinations with chemical herbicides. Majority of allelochemicals are secondary metabolites and belongs to different chemical families. Allelochemicals exhibit their effect by targeting important physiological and biochemical processes of plants. Identification of suitable allelochemicals will not only help to develop natural herbicide but also reduce dependence on chemical herbicides. Allelopathic potential is identified in various food as well forage crops like sorghum, oat, alfalfa, rye, rice sunflower, wheat, beet, etc. that can be exploited for weed control in agricultural system very effectively. Variety of different agricultural practices can be adopted for sustainable weed management and agricultural crop production by using the allelopathic crops. Agricultural practices like mulching, intercropping, crop rotation, smoother crops, crop covers and green manures etc. proved to be the better practices towards better weed managements and increased the crop production. Therefore, present review focus on different dimensions of crop allelopathy and its potential as a most sought green technology towards weed management and sustainable agriculture production.
\end{abstract}

\section{Article Info}

Accepted: 16 March 2016

Available Online: 06 April 2016

Ke ywords

Allelochemicals

Allelopathy

Crop production

Herbicides

Weed managements

\section{Introduction}

Weeds are among one of major threat for crop plants, as they competes with crop plants for natural resources, leading to suppress the plant growth as well as loss of yield to substantial extent. As population is increasing, there is a continuous pressure on food demand. Therefore there is a major concern to address weed mediated decline in crop production by adopting different weed management strategies. Among these, allelopathy could be a potential tool towards achieving sustainable and integrated weed control management. Allelopathic crops can provide alternative and cost effective method to reduce weed pressure. Allelopathy is well known natural ecological phenomenon and used in agriculture system and usually mediated by release of certain chemical 
substances. These chemical substances are normally secondary metabolites, produced during various physiological and biochemical processes as by-product. (Farooq et al., 2011; Bhadoria, 2011). The active biomolecules commonly referred as allelochemicals released by allelopathic plants affects the basic functioning of other organisms or plant present near the releasing plant or organism (Bertin et al., 2003). Allelopathy involves the release of allelochemicals and diffuse into the soil from allelopathic plant and exhibits its beneficial or adverse effect on target plant or microorganisms. Therefore, allelopathic effect may be growth promoting or inhibitory (Rice, 1984).

Molisch (1937), a plant physiologist introduced the term allelopathy, which is a hybrid made from two greek words,i.e, allelon $=$ 'mutual' and pathos $=$ 'to suffer' (Chon and Nelson, 2012). Mostly the secondary metabolites like phenolics, alkaloids, flavonoids are recognised as an allelochemicals. Studies on allelopathic interaction on different organism indicated that the allelopathy has immense potential to improve crop production, through maintaining ecosystem stability as well as nutrient conservation and weed management (Kong et al., 2004). The role of allelopathy in weed management provides valuable ecofriendly approach, moreover the use of allelopathic potential of different crops against various weed communities could be a environmental friendly solution for reducing the dependence on use of chemical herbicides (Inderjit et al., 2005).

The allelochemicals release from donor plants establish their chemical communication by interacting at various levels i.e., between plant-herbivore, plantinsect and within plant-plant in order to show their effect (Weir et al., 2004) similarly, allelochemicals derived from microbes play a vital role in colonization process of microbes under new ambience by interacting at microbe -microbe or microbe-plant level (Singh et al., 2003). In the present worldwide scenario and need to identify cost effective and ecofriendly weed management system motivated the people towards deciphering the role of allelopathic interaction between crops and weeds (Dudai et al., 1999; Om et al., 2002). There are several crops studied for their allelopathic potential for example alfalfa (Xuan et al., 2005), barley, black mustard, buckwheat, rice (Kirn and Shin, 2005), sorghum, sunflower (Khanh et al., 2005) and sesame (Kumar and Varshney, 2008), have shown substantial allelopathic potential to suppress weed growth.
Autotoxicity is another dimension of allelopathy, and most prevalent in many crops. Where, allelochemicals released from one plant species suppress or inhibit the growth and germination of the same plant species. Autotoxicity is well observed in legume crops, leading to reduction in crop yield, this could be attributed to auto toxicity, because most of the legume crops are cultivated as monocropping system (Millar, 1996; Singh et al., 1999).

Although the efficiency and specificity of allelochemicals are limited yet there are big advantages of applications of allelochemicals like no residual toxic effect left behind beside inhibiting the germination and growth of weeds. Therefore, allelochemicals are suitable candidate as herbicide and can be replaced with chemical herbicides (Bhadoria, 2011).

\section{Allelochemicals}

Allelochemicals are active biomolecules (chemicals) released by plants or microbes into the surrounding environment. Allelochemicals gets accumulated in the soil and display a massive negative impact on the growth and yield on other crop plants of upcoming season (Rice 1984). Allelochemicals are released from plant parts, residues or disintegrated plant or microbes. Plants or microbes produce allelochemicals as by products of various metabolic activities and released as secondary metabolite by living plant parts or disintegrated product of plants or microbes. Biologically derived allelochemicals are the key component of allelopathy and are classified into 14 broad categories (Rice, 1974). Such cateogarization of allelochemicals were on the bases of their chemical similarity belonging to different chemical families i.e., water-soluble organic acids, straight long chain alcohols, aliphatic aldehydes, and ketones; simple Unsaturated lactones; long-chain fatty acid sand polyacetylenes; benzoquinone, anthraquinone and complex quinones; simple phenols, benzoic acid and its derivatives; cinnamic acid and its derivatives; coumarin; flavonoids; tannins; terpenoids and steroids; amino acids and peptides; alkaloids and cyanohydrins; sulfide and glucosinolates; and purines and nucleosides.

Beside these chemicals, phytoharmones and plant growth regulator compounds like gibberellic acid, ethylene and salicylic acid are also considered as allelochemicals in one or other way. Although there are thousands of secondary compounds are identified but not all exhibit the allelopathic properties rather only few are considered as allelochemicals (Rice, 1984). 
Kruse et al. (2000) and Jabran and Farooq (2012) have identified, some of the basic secondary metabolites like phenolics, alkaloids, flavonoids, terpenoids, momilactone, hydroxamic acids, brassinosteroids, jasmonates, salicylates, glucosinolates, carbohydrates and amino acids as allelochemicals. Further, mode of action of such allelochemicals is strictly concentration dependent and their effect on germination or plant growth may be inhibitory or promotive is determined by high or low concentration of allelochemicals (Einhellig, 1986). It was also observed that, usually allelochemicals exhibit inhibitory role on plant growth when present in high concentration, where as induce plant growth at low concentrations (Narwal, 1994). Therefore, using allelochemicals in high concentration can potentially be exploited as natural pesticides (Farooq et al., 2009c).

Putnam (1988) has suggested 6 broad classes of allelochemicals which can be potentially used as herbicides, such allelochemicals were isolated from aquatic and terrestrial plants belonging to various families. These allelochemicals such as, alkaloids, benzoxazinones, cinnamic acid derivatives, cyanogenic compounds, ethylene and other seed germination stimulants, and flavonoids possess properties of potential phytotoxicity.

Moreover, various studies suggested that allelochemicals can only impart their effect on target plants, if released into surrounding environment by allelopathic plant. Therefore to achieve allelopathic effect, allelochemical must release into the surrounding environment. The allelochemicals, released into the environment by adopting various methods like root exudation, decay of plant parts, residues, volatilization and leaching from disintegrated plant parts following the rain in to the soil. (Mann, 1987). The leaves of black walnut, Juglans nigra, suppress the growth of vegetation near or under the walnut plant because of the release of phytotoxins leading to runoff by rain. (Bode, 1958).

The application of dead and decomposed plant material which release allelochemicals (phytotoxins), such materials can be applied as mulching agents to suppress the weed, for example rye, which inhibits seed germination as well as growth by releasing phytotoxic compounds (Barnes and Putnam, 1986). Further, studies indicated that green parts of the plants can also release of volatile phytotoxic compounds for example Salvia leucophylla and Artemisia californica (Halligan, 1973) and roots of rice plants release allelochemicals which selectively inhibit weed growth (Olofsdotter et al., 1997).

\section{Mode of action of allelochemicals}

Allelochemicals are very strong chemicals agents which target crucial processes in plants to alter various physiological and biochemical processes in order to exhibit their allelopathic effect. Such allelochemicals target important physiological processes like respiration, transpiration, mineral uptakes, photosynthesis, etc. that results into plant growth inhibition, stomatal closure, alteration of mineral uptake, alteration in enzyme activities, induction of moisture stress and hormonal imbalance. (Zeng et al., 2001; Gniazdowska and Bogatek, 2005). Further, allelochemicals also involved in altering the micro and ultra structure of cells, altering protein and nucleic acid biosynthesis, imbalance of antioxidant enzymes and influence on plant growth regulators. Moreover, the effect of allochemicals on microbial community and ecological environment is equally effective. (Cheng and Cheng, 2015). Various studies conducted on allelochemicals to determine their role in different crop plants. The effect of allelochemicals on roots of $P$. vulgaris indicated the disordered cell organization and ill defines differentiated root tip cells, where root tip cells were extruded together (Cruz et al., 1998).

It was observed that allelochemicals like benzoic acid and trans-cinnamic acid displayed the inhibitory effect on growth of Glycine max (soyabean). The growth inhibition could be due to alteration of ion uptake and transport, decrese of chlorophyll content. Further, there were reduction in phosphorous, poatssium, magnesium and magnese contents in shoots and roots of soyabean observed (Baziramakenga et al., 1994). It also revealed that compound like benzoic, cinnamic, vanillic and ferulic acids inhibit the growth of soybean plant by interfering with phosphorous uptake, nucleic acid and protein metabolism (Baziramakenga et al., 1997). Studies indicated that sorgoleone an effective allelochemical of Sorghum (Sorghum bicolor L.) effects on photosynthesis system and act as a strong inhibitor of electron transport in photo system II (PSII) in crop plants leading to inhibition of oxygen evolution in plants (Nimbal et al., 1996; Einhellig and Souza, 1992).

\section{Allelopathic crops}

Allelopathic potential have been explored in many different food and fodder crops belonging to various families. Some of the crops like wheat (Triticum aestivum L.), maize (Zea mays L.), oats (Avena sativa L.) and barley (Hordeum vulgare L.), beet (Beta vulgaris L.) 
and lupin (Lupinus lutens L.) have shown allelopathic effect on other crops (Rice, 1984b). Weston 1996, indicated the allelopathic potential by releasing of allelochemicals in other crops like Black mustard (Brassica nigra L.), Buck wheat (Fagopyrium esculentum L.) Clovers (Trifolium spp.) and sweet clover (Melilotus spp.). Rye (Secale cereale L.), the most important crop plants belonging wheat tribe is cultivated mainly for a grain and as forage crop. It showed immense allelopathic potential and capable to inhibit the growth of weeds ((Miller, 1996). Its allelopathic activity is due to root exudates containing allelochemicals, that effectively suppress weed growth, therefore can be used as natural herbicide and as cover crop for weed management as well (Kruse et al., 2000; Pérez and Ormeno-Nunez, 1993). The shoot and root residues of rye plants can effectively suppress weed growth as study conducted on barnyard grass observed that root residues are more effective than shoot (Kohli et al., 2001). Varity of natural allelochemicals were identified in rye crop, such chemicals contributed to its allelopathic potential and shows herbicidal activities. Some of most effective allelochemicals include, phenolic acids, hydroxamic acids [2,4-dihydroxy$1,4(2 \mathrm{H})$ - benzoxazin-3-one (DIBOA), 2(3H)benzoxazolinone (BOA) and 2,2'-oxo-1,1'-azobenzene , (AZOB) is a compound formed by the microbial transformation of rye residues (Kruse et al., 2000; Reberg-Horton et al., 2005).

Allelopathic potential and weed suppressive ability were reported in various Brassica spp, which are cultivated or wildly grown. Some of these crops have shown inhibitory effect leading to poor seed germination, reduced growth and emergence of small grain in next crops, when grown in rotation (Bialy et al., 1990).

Fenwick et al. (1983) identified presence of high amounts of glucosinolates in (Brassica nigra L.) Brassica spp. Moreover, some studies indicated that different plant parts (like, stem, leaf, flower and root) of black mustard exihibit allelopathic effect on various crops like alfalfa, lentil, wild oat and radish and effectively suppress the seed germination and seedling growth when used their water extract (Turk et al., 2005; Muahammad et al., 2013).

Alfalfa, (Medicago sativa L.) is among one of the important forage crop. Which cultivated worldwide as fodder for cattle and reportedly produces number of allelochemicals, leading to cause autotoxicity to the this crop. These water soluble autotoxic chemical compounds are usually found in root and shoot, althought such chemicals are more concentrated in root than shoot. However, there are indications that certain chemicals like chlorogenic acid, saponin, medicarpin and other phenol like substances may be involved in alfa alfa autoxicity (Hall and Henderlong, 1989; Dornbos et al., 1990). Although it is not very clear that which chemical compound is mainly responsible for autotoxicity in alfalfa but having grown new crop on old alfalfa stand is severely experience autotoxic effects which includes reduced seed germination, less growth of root and shoot and poor productivity (Seguin et al., 2002).

Sorghum (Sorghum bicolor L.) is widely cultivated fodder crop possess allelopathic potential, its root hairs contains high concentration of main allelochemical, sorgoleone (2- hydroxy- 5- methoxy- 3- [(8'Z, ll'Z)- $8^{\prime}$ ,11',14' - pentadecatriene]- p- benzoquinon) and released in surrounding environment . it was isolated and identified from hydrophobic oil like root exudates. (Netzley and Butler 1986). Sorgoleon, the major pbenzoquinones along with other three minor pbenzoquinones together contribute more than $90 \%$ of the root exudates in sorghum (Dayan et al., 2007). Since sorgleon mimic the effect of diurontype herbicides, for example $s$-triazines, triazinones, biscarbamates, ureas, phenylureas and uracils it can be used as a natural herbicides(Streibig et al,. 1999). It was estimated that concentrated sorghum water extract sufficiently inhibit weed density (15-47\%) and dry weight (19-49\%) in different weeds like Chenopodium album, Phalaris minor, Fumaria indica and Rumex dentatus in wheat crop (Cheema and Khaliq, 2000).

Rice (Oryza sativa L.) is an important staple food crop for humans consumption worldwide. It allelopathic activity was studied against Echinochloa crusgalli $\mathrm{P}$. Beauv. var. oryzi-cola Ohwi (barnyard grass), commonly associated weeds of rice (Chung et al., 2003). Large number of allelochemicals were identified and screened in rice extract and exudates for their allelopathic potential. Such chemicals were belonging to different chemical classes, namely, fatty acids, indoles, benzoxazinoids, phenylalkanoic acids, phenolic acids and terpenoids. Belz , 2007; Kato-Noguchi et al., 2008). An important allelochemical from rice, momilactone B diterpenoid has been suggested as an effective allelochemical for weed suppression (Kato-Noguchi and Ino, 2005).

The allelopathic potential of sunflower (Helianthus annuus L.) can be used as natural herbicide against 
weeds especially against broad leaf weeds (Bogatek et al., 2006; Anjum and Bajwa, 2007). According to Om et al. (2002) application of sunflower as green manure can significantly inhibit (42-100\%) of the population of Phalaris minor Retz., under both feld and laboratory conditions, respectively. Certain phenolic compounds like, diterpens and triterpense were isolated from sunflower (Helianthus annuus L.) which has shown promising alleopatic activity (Macías et al., 2004b).

\section{Allelopathy and sustainable crop production}

Weeds are major bottle neck in agricultural crop production systems, weeds not only share the space but also capture the essential nutrient resources required for the growth of crop plant (Smith et al., 2010). Therefore causes a considerable decrease in crop production as well as soil health (Sharma, 2014). Therefore, such allelopathic crop can be potentially exploited as proper weed management tool. Biosynthesis of allelochemicals in microorganisms and higher plants, proves to be useful as natural herbicides, in recent years many experts are working on the these crops due to the direct effect of allelopathic weed plants to use as a method of weed management (Rahimiyan et al., 1994). These allelopathic crops can use in multiple ways to reduce weed pressure for example, as a smother crop, crop rotation in sequence, as residue or mulch. Crop rotation in sequence is also proved to be effective practice to substantially reduce weed density, as evident from the study on rice- wheat cropping system. When changed, there is reduction in weed density and weed dry matter production. Rice-wheat-green gram sequence was most effective in suppressing weeds growth followed by rice-wheat, rice-chickpea and rice-pea sequence (Singh et al., 2012).

Allelopathy provides an effective and natural mean to control over weeds, beside effective weed management allelochemicals have shown promising potential over insect-pests and diseases management. Most of the allelochemicals are secondary metabolites therefore their role in abiotic stress tolerance in crop plants cannot be ignored since secondary metabolites as stress signal molecules play a key role in defense against abiotic stresses (Maqbool et al., 2013).

Various studies indicated that, not only the application of water extract of allelopathic crops, allelopathy can also play effective role in controlling weeds growth through allelochemicals incorporated into soil due to disintegration or decay of allelopathic crop residues or leaching. Mulching of allelopathic crop residues also provide one of the effective mean to suppress weeds with no use of chemical herbicides (Jabran,K et al., 2015; Awasthy et al., 2014). Allelopathy provides immense opportunity towards weed management and sustainable crop production, there are various approaches can be exploited for harnessing maximum potential of allelopathy under weed management. Approaches like intercropping and crop rotation of certain allelopathic crops to kill weeds by inducing allelopathic effect in soil (Iqbal et al., 2007).

Beside weed suppression intercropping also reduces the cost of weed eradication and increase crop yield. Intercropping of sugarcane with greengram was more effective and recorded less weed dry weight and more sugarcane productivity as compared to cropping of os sugarcane alone (Bhullar et al., 2006). There are studies that indicated that weed suppression is very effective when inercropping ehihibit strong competitive environment against weeds under specific conditions i.e, time or space (Dwivedi et al., 2012).

Moreover, the effectiveness of allelopathic application approaches depends on environmental factors and proper weed management strategies, such applications are not only capable of reducing weeds significantly but also have natural potential to reduce weed growth. Further, dependence on chemical herbicides also reduces when used as mixture of water extract of allelopathic potential with less dose of chemical herbicide (Cheema et al., 2012).

The studies on allelopathic effect of wheat on weeds have shown a significant effect (Bertholdsson, 2011; Wu et al., 2007). Study on allelopathic potential of different wheat cultivars (Modern Wheat, Triticale, Rye and Wheat Breeding Lines) exhibited that cultivar triticale Dinaro has shown maximum allelopathic inhibition of black-grass biomass and the new wheat cultivar Nimbus was next to it, therefore can potentially used in weed management, further, study on wheat-rye translocation lines also exhibited as good activity as of triticale and the best wheat cultivars (Bertholdsson, 2012). Study on rye indicated that aqueous extracts of rye residues can suppress horseweed (Conyza canadensis L.) and willowherb (Epilobium ciliatum Rafin) (Wu, H. Pratley, 2003).

Application of different green agricultural practices may help in sustainable crop production, such practices creates conditions that do not support weed germination 
and their growth. Such practices also helps to maintain soil fertility, preserving organic matter and reduce soil loss (Norris and Kogan, 2000). Thus there is a major thrust on adoption of the sustainable agriculture approaches exploiting allelopathic potential of crops, that could help to sustain agricultural production through proper weed management.

\section{Conclusion}

Allelopathy is a ntural ecological phenomenon and is know in agriculture system since encient time. allelopathy offers an immense potential in the field of sustainable agriculture system and ecofriendly weed management exploiting plant allelochemicals, moreover, deciphering the allelopathic potential of diverse crop plants and adoption of suitable green agricultural practices will help effective weed management and sustainable crop production. However, for successful implimentation of allelopathic potential, it needs the deep understanding of plant physiology and ecology of crop plants. Allelochemicals released into the environment and impart their allelopathic effects on weeds. Allelochemicals are as effective as chemical herbicides, therefore they are suitable candidate to be replaced with chemical herbicides and may provide an alternative green weed management tool. Several allelochemicals are isolated and identified so far, However, their applications are still very limited and restricted. Moreover, the broad spectrum application of allelochemicals requires more understanding of mechanism of release of allelochemicals, mode of action, interaction with soil and other chemicals, along with various environmental factors to harness their maximum potential in agricultural system.

\section{Conflict of interest statement}

Authors declare that they have no conflict of interest.

\section{References}

Anjum, T., Bajwa, R., 2007. Field appraisal of herbicide potential of sunflower leaf extract against Rumex dentatus. Field Crops Res. 100, 139-142.

Awasthy, P., Bhambri, M. C., Pandey, N., Bajpai, R. K., Dwivedi, S. K., 2014. Effect of water management and mulches on weed dynamics and yield of maize. Ecoscan. (6), 473-478.

Baziramakenga, R., Leroux, G.D., Simard, R.R., Nadeau, P., 1997. Allelopathic effects of phenolic acids on nucleic acid and protein levels in soybean seedlings. Can. J. Bot. $75,445-450$.
Baziramakenga, R., Simard, R.R., Leroux, G.D., 1994. Effects of benzoic and cinnamic acids on growth, mineral composition and chlorophyll content of soybean roots. J. Chem. Ecol. 20, 2821-2833.

Belz, R.G., 2007. Allelopathy in crop/weed interactions. An update. Pest Manag. Sci. 63(4), 308-326.

Bertholdsson, N. O., 2012. Allelopathy-A tool to improve the weed competitive ability of wheat with herbicideresistant black-grass (Alopecurus myosuroides Huds.) Agron. 2, 284-294.

Bertholdsson, N.O., 2011. Use of multivariate statistics to separate allelopathic and competitive factors influencing weed suppression ability in winter wheat. Weed Res. (51), 273-283.

Bertin C., Yang X., Weston L.A. 2003. The role of root exudates and allelochemicals in the rhizosphere, Plant Soil 256, 67-83.

Bhadoria, P.B.S., 2011. Allelopathy: A natural way towards weed management. Amer. J. Exp. Agric. 1(1), 7-20.

Bhullar, M. S., Kamboj, A., Singh, G. P., 2006. Weed management in spring planted sugarcane-based intercropping system. Ind. J. Agron. 51(3), 183-185.

Bialy, Z., Oleszek, W., Lewis, J., Fenwick, G.R., 1990. Allelopathy potential of glucosinolates (mustard oil glycosides) and their degradation products against wheat. Plant Soil. 129, 177-181.

Bode, H. R., 1958. Beiträge zur Kenntnis allelopatischer Ercheinungen bei einigen Juglandaceen. Planta 51, 440-480.

Bogatek, R., Gniazdowska A., Zakrzewska W., Orac K., Gawronski, S.W. 2006. Allelopathic effects of sunflower extracts on mustard seed germination and seedling growth, Biol. Plant. 50, 156-158.

Cheema, Z.A., Farooq, M., Khaliq, A., 2012. Application of allelopathy in crop production: Success story from Pakistan. In: Allelopathy: Current Trends and Future Applications. pp.113-143.

Cheema, Z.A., Khaliq, A., 2000. Use of sorghum allelopathic properties to control weeds in irrigated wheat in semi arid region of Punjab. Agric. Ecosyst. Environ. 79, 105-112.

Cheng, F., Cheng, Z., 2015. Research progress on the use of plant allelopathy in agriculture and the physiological and ecological mechanisms of allelopathy. Front. Plant Sci. 6, 1020.

Chon, S.U., Nelson, C.J., 2012. Allelopathic dynamics in resource plants. In: Allelopathy: Current Trends and Future Applications. pp.81-110.

Chung, I. M., Kim, K. H., Ahn, J. K., Lee, S. B., Kim, S. H., Hahn, S. J., 2003. Comparison of allelopathic potential of rice leaves, straw, and hull extracts on Barnyard grass. Agron. J. (95), 1063-1070.

Cruz, O.R., Anaya, A.L., Hernandez-Bautista, B.E., 1998. Effects of allelochemical stress produced by Sicyos deppei on seedling root ultrastructure of Phaseolous valgaris and Cucubita ficifolia. J. Chem. Ecol. 24, 2039-2057.

Cruz, O.R., Anaya, A.L., Ramos, L., 1988. Effects of allelopathic compounds of corn pollen on respiration and cell division of watermelon. J. Chem. Ecol. 14, 71-86. 
Dayan, F.E., Watson, S.B., Nanayakkara, N.P.D., 2007. Biosynthesis of lipid resorcinols and benzoquinones in isolated secretory plant root hairs, J. Exp. Bot. 58, 32633272.

Dornbos, D.L. Jr., Spencer, G.F., Miller, R.W., 1990. Medicarpin delays alfalfa seed germination and seedling growth, Crop Sci. 30, 162-166.

Dudai, N., Poljakoff-Mayber, A., Mayer, A.M., Putievsky, E., Lerner, H.R., 1999. Essential oils as allelochemicals and their potential use as bioherbicides, J. Chem. Ecol. 25, 1079-1089.

Dwivedi, S. K., Shrivastava, G. K., Singh, A. P., Lakpale, R., 2012. Weeds and crop productivity of maize + blackgram intercropping system in Chhattisgarh plains. Indian J. Weed Sci. 44, 26-29.

Einhellig, F.A., 1986. Mechanisms and modes of action of allelochemicals. In: The Science of Allelopathy (Eds.: Putnam, A.R., Tang, C.S.). Wiley, New York, USA. pp. 171-187.

Einhellig, F.A., Souza, I.F., 1992. Phytotoxicity of sorgoleone found in grain sorghum root exudates. J. Chem. Ecol. 18, $1-11$.

Farooq, M., Bajwa, A.A., Cheema, S.A., Cheema, Z.A., 2013. Application of allelopathy in crop production. Int. J. Agric. Biol. 15, 1367-1378.

Farooq, M., Jabran, K., Cheema, Z.A., Wahid, A., Siddique, K.H.M., 2011. The role of allelopathy in agricultural pest management. Pest Manage. Sci. 67, 493-506.

Farooq, M., Wahid, A., Kobayashi, N., Fujita, D., Basra, S.M.A., 2009. Plant drought stress: Effects, mechanisms and management. Agron. Sustain. Dev. 28, 185-212.

Fenwick, G.R., Heaney, R.K., Mullin, W.J., 1983. Glucosinolates and their breakdown products in food and food plants. Crit. Rev. Food Sci. Nutr. 18, 123-301.

Gniazdowska,A., Bogatek, R., 2005. Allelopathic interactions between plants. Multi site action of allelochemicals. Acta Physiol. Plant. 27, 395-407.

Hall, M.H., Henderlong, P.R., 1989. Alfalfa autotoxic fraction characterization and initial separation, Crop Sci. 29, 425-428.

Halligan, J. P., 1973. Bare areas associated with shrub stands in grasslands: the case of Artemisia california. Biosci. 23, 429-432.

Inderjit, Weston, L. A.., Duke, S. O., 2005. Challenge, achievements and opportunities in allelopathy research. J. Plant Interact. 1(2), 69-81.

Iqbal, J., Cheema, Z.A., An, M., 2007. Intercropping of field crops in cotton for the management of purple nuts edge (Cyperus rotundus L.). Plant Soil. 300, 163-171.

Jabran, K., Farooq, M., Aziz, T., Siddique, K.H.M., 2012. Allelopathy and crop nutrition. In: Allelopathy: Current Trends and Future Applications. pp.113-143.

Jabran,K., Mahajan, G., Sardana, V., Chauhan, B.S., 2015. Allelopathy for weed control in agricultural systems. Crop. Prot. 72, 57-65.

Kato-Noguchi, H., Ino, T., 2005. Possible involvement of momilactone B in rice allelopathy, J. Plant Physiol. 162, 718-721.
Kato-Noguchi, H., Ino, T., Ota, K., 2008. Secretion of momilactone A from rice roots to the rhizosphere, J. Plant Physiol. 165, 691-696.

Khanh, T.D., Chung, I.M., Xuan, T.D., Tawata, S., 2005. The exploitation of allelopathy in sustainable agricultural production. J. Agron. Crop Sci. 191, 172-184.

Kim, K. U., Shin, D. H. 2005. Allelopathic research and development. A world view on breeding of allelopathic rice. In: Proc. of the $20^{\text {th }}$ Asian Pacific Weed Sci. Soc. Conf., Vietnam. pp.35-44.

Kohli, R.K., Singh, H.P., Batish, D.R., 2001. Allelopathy in Agroecosystems. The Haworth Press, Inc.

Kong, C. H., Liang, W. J., Xu, X. H., Hu, F., Wang, P., Jiang, Y., 2004. Release and activity of allelochemicals from allelopathic rice seedlings. J. Agric. Food Chem. 52, 2861 2865.

Kruse, M., Strandberg, M., Strandberg, B., 2000. Ecological Effects of Allelopathic Plants-A Review. Department of Terrestrial Ecology, Silkeborg, Denmark, Rep. No. 315.

Kumar, L., Varshney, J. G., 2008. Efficacy of sesame root exudates against major weeds of pulse crops. Ind. J. Agric. Sci. 78(10), 842-847.

Macías F.A., Molinillo, J.M.G., Chinchilla, D., Galindo, J.C.G., 2004. Heliannanes - A structure-activity relationship (SAR) study. In: Allelopathy: Chemistry and Mode of Action of Allelochemicals (Eds.: Macías, F.A., Galindo, J.C.G., Molinillo, J.M.G., Cuttler, H.G.). CRC Press, Boca Raton, Florida. pp.103-124.

Mann, J., 1987. Secondary Metabolism. $2^{\text {nd }}$ Edition. Clarendon Press, Oxford. 374p.

Maqbool, N., Wahid, A., Farooq, M., Cheema, Z.A., Siddique, K.H.M., 2013. Allelopathy and abiotic stress interaction in crop plants. In: Allelopathy (Eds.: Cheema, Z., Farooq, M., Wahid, A.) Springer Berlin Heidelberg, Berlin. pp.451-468.

Miller, D.A., 1996. Allelopathy in forage crop systems, Agron. J. 88, 854-859.

Molisch, H., 1937. Der Einfluss einer Pflanze auf die AndereAllelopathic. Fischer, Jena, Germany. 31, 12-16.

Muahmmad, W.U.R., Muhammad, H., Mubasher, A. Ch., Basit Mustafa, J. S., Faisal, I., 2013. Allelopathy of Brassica. A review. Sci. Agric. 3(2), 46-53.

Narwal, S.S., 1994. Allelopathy in Crop Production. 288p. Scientific Publishers, Jodhpur, India.

Netzly, D.H., Butler, L.G., 1986. Roots of sorghum exude hydrophobic droplets containing biologically active components. Crop Sci. 26, 775-778.

Nimbal, C.I., Pedersen, J.F., Yerkes, C.N., Weston, L.A., Weller, S.C., 1996. Phytotoxicity and distribution of sorgoleone in grain sorghum germplasm. J. Agric. Food Chem. 44, 1343-1347.

Norris, R. F., Kogan, M., 2000. Interactions between weeds, arthropod pests, and their natural enemies in managed ecosystems. Weed Sci. 48, 94-158.

Olofsdotter, M., Navarez, D., Rebulanan, M., 1997. Rice allelopathy - where are we and how far can we get? Brighton Crop Protect. Conf. Weed. 1, 99-104. 
Om, H., Dhiman, S.D., Kumar, S., Kumar, H., 2002. Allelopathic response of Phalaris minor to crop and weed plants in rice-wheat system. Crop Prot. 21, 699-705.

Pérez, F.J., Ormeno-Nunez, J.,1993. Weed growth interference from temperate cereals: the effect of a hydroxamic-acidsexuding rye (Secale cereale L.) cultivar. Weed Res. 33, 115-119.

Putnam,A.R., 1988. Allelochemicals from plants as herbicides. Weed Tech. 2, 510-518.

Rahimiyan, H., Koochaki, A.S., Nassiri, H., Khiyabani, H., 1994. Weed Ecology (translation). Jahad Mashhad University Press. 327p.

Reberg-Horton, S.C., Burton, J.D., Daneower, D.A., Ma, G., Monks, D.W., Murphy, J.P., Ranells, N.N., Williamson, J.D., Creamer, N.G., 2005. Changes over time in the allelochemical content of ten cultivars of rye (Secale cereale L.). J. Chem. Ecol. 31, 179-193.

Rice, E.L., 1984. Allelopathy, $2^{\text {nd }}$ Edn., Academic Press, New York. 422p.

Rice, E.L., 1974. Allelopathy. Academic Press, NewYork.

Seguin, P., Sheaffer, C.C., Schmitt, M.A., Russelle, M.P., Randall, G.W., Peterson, P.R., Hoverstad, T.R., Quiring S.R., Swanson, D.R., 2002. Alfalfa autotoxicity: Effects of reseeding delay, original stand age, and cultivar, Agron. J. (94), 775-781.

Sharma, A.R., 2014. Weed management in conservation agriculture systems-problems and prospects. National Training on Advances in Weed Management. pp.1-9.

Singh, H.P., Batish, D.R., Kohli, R.K., 2003. Allelopathic interactions and allelochemicals: New possibilities for sustainable weed management, Crit. Rev. Plant Sci. 22, 239-311.

Singh, A., Kaur, R., Kang, J. S., Singh, G., 2012. Weed dynamics in rice-wheat cropping system. Global J. Biol. Agric. Health Sci. 1(1), 7-16.
Singh, H.P., Batish, D.R., Kohli, R.K., 1999. Autotoxicity: concept, organisms and ecological significance. Crit. Rev. Plant Sci. 18, 757-772.

Smith, R. G., Mortensen, D. A., Ryan, M. R., 2010. A new hypothesis for the functional role of diversity in mediating resource pools and weed-crop competition in agroecosystems. Weed Res. 50, 37-48.

Streibig, J.D., Dayan, F.E., Rimando, A.M., Duke, S.O., 1999. Joint action of natural and synthetic photosystem II inhibitors, Pestic. Sci. 55, 137-146.

Turk, M.A., Lee, K.D., Tawaha, A.M., 2005. Inhibitory effects of aqueous extracts of black mustard on germination and growth of radish. Res. J. Agric. Biol. Sci. 1, 227-231.

Weir, T.L., Park, S.-W., Vivanco, J.M., 2004. Biochemical and physiological mechanisms mediated by allelochemicals, Curr. Opin. Plant Biol. 7, 472-479.

Weston, L.A., 1996. Utilization of allelopathy for weed management in agro-ecosystems. Agron. J. 88, 860-866.

Wu, H., Pratley, J., Haig, T., 2003. Phytotoxic effects of wheat extracts on a herbicide-resistant biotype of annual ryegrass (Lolium rigidum). J. Agric. Food Chem. 51, $4610-4616$.

Wu, H., Pratley, J., Lemerle, D., An, M., Liu, D.L., 2007. Autotoxicity of wheat (Triticum aestivum L.) as determined by laboratory bioassays. Plant Soil. 296, 8593.

Xuan, T. D., Tawata, S., Khanh, T. D., Chung, I. M., 2005. Decomposition of allelopathic plants in soil. J. Agron. Crop Sci. 191, 162-171.

Zeng, R.S., Luo, S.M., Shi, Y.H., Shi, M.B., Tu, C.Y., 2001. Physiological and biochemical mechanism of allelopathy of secalonic acid for higher plants. Agron. J. 93, 72-79.

\section{How to cite this article:}

Saxena, R., Tomar, R. S., Kumar, M., 2016. Allelopathy: A green approach for weed management and crop production. Int. J. Curr. Res. Biosci. Plant Biol. 3(4), 43-50. doi: $\underline{\text { http://dx.doi.org/10.20546/ijcrbp.2016.304.008 }}$ 